\title{
Abnormal serum IgG subclass pattern in children with Down's syndrome
}

\author{
G Annerén, C G M Magnusson, G Lilja, S L Nordvall
}

\begin{abstract}
Susceptibility to infections is a well known feature of Down's syndrome. The possible relation between this predisposition and the serum concentrations of the IgG subclasses was studied in 38 children with Down's syndrome aged 1-12 years. An age matched group of 50 healthy children served as controls. The serum concentrations of $\mathbf{I g G}_{1}$ and $\mathbf{I g G}_{3}$ were significantly raised among children with Down's syndrome in all three age groups studied (that is $1-2 \cdot 5,4-8$, and 9-12 years). The serum concentrations of $\mathbf{I g G}_{2}$ were normal in the first two groups but significantly reduced in the third age group. In contrast, the concentrations of $\mathbf{I g G}_{4}$ among children with Down's syndrome were significantly reduced in all three age groups. Moreover, among the children with Down's syndrome aged $4-12$ years $68 \%(15 / 22)$ had IgG $_{4}$ concentrations below 2 SDs of the geometrical mean of the controls. The results may partially explain the proneness of children with Down's syndrome to infections with encapsulated bacteria. Although the underlying cause of these abnormalities is unknown, IgG subclass determination seems relevant in the clinical evaluation of children with Down's syndrome.
\end{abstract}

Susceptibility to infections is a feature of Down's syndrome, and is likely to be due to abnormalities of host defence, that is, of the immune response. Reported defects include components of cell mediated ${ }^{\mathbf{l}}$ and humoral immunity, ${ }^{2}$ the inflammatory response, ${ }^{34}$ and interferon production. ${ }^{56}$ The results of studies of serum immunoglobulin concentrations in subjects with Down's syndrome have been conflicting. Both normal and raised serum concentrations of $\operatorname{IgG}, \operatorname{IgA}$, and $\operatorname{IgE}$ have been found and raised, normal, and decreased concentrations of IgD. ${ }^{17}$ In adults with Down's syndrome the serum concentrations of $\mathrm{IgG}_{2}$ and $\mathrm{IgG}_{4}$ have been found to be significantly reduced and those of $\operatorname{IgG}_{1}$ and $\mathrm{IgG}_{3}$ to be normal or raised. ${ }^{8}$ Recently it has been claimed that about half of the children with Down's syndrome are deficient in $\operatorname{IgG}_{4} .^{9}$ The aim of the present study was to investigate the serum concentrations of all IgG subclasses in children with Down's syndrome and to compare them with those in healthy children of the same ages.

Patients and methods

The study comprised 38 non-institutionalised children with chromosomally verified Down's syndrome, 16 girls and 22 boys, who were aged 1 to 12 years. Nine of these patients had congenital cardiovascular malformations, none of which was of major clinical significance. Three of the patients had been operated upon in the neonatal period for treatment of congenital gastrointestinal malformations, and none of them suffered subsequently from any complications of these conditions. In the 38 children with Down's syndrome blood samples were taken for serum IgG subclass determination. A brief interview with the parents concerning the dietary habits of the children confirmed that they had a normal diet. The proneness to infectious diseases was evaluated and the children underwent physical investigation at the time of blood sampling. None of them showed signs of current infection at that time.

Fifty age matched healthy children served as controls and because of the age dependency of IgG subclass concentrations, particularly $\operatorname{IgG}_{2}$ and $\mathrm{IgG}_{4}$ in early childhood, ${ }^{10}$ the children were split into three age groups: $1-2 \cdot 5,4-8$, and $9-12$ years. There were 16,12 , and 10 children with Down's syndrome and 20,15, and 15 control children in the three age groups respectively.

The serum samples were stored at $-20^{\circ} \mathrm{C}$ before analysis. The concentrations of the subclasses of IgG were determined by a competitive two step microtitre enzyme linked immunosorbent assay (ELISA) based on subclass specific monoclonal antibodies. The assay conditions regarding the buffers used, incubation times, and sample dilutions, and the specificity, sensitivity, linearity, precision, and accuracy will be described in detail elsewhere (C G M Magnusson, to be published). All serum samples were assayed in duplicate and a commercial standard serum ( $\mathrm{H} 00-03$, Janssen, Belgium), calibrated against the WHO 67/97 standard, ${ }^{11}$ was used to produce standard curves. The interassay imprecision, which was evaluated by including two dilutions of a control serum on each plate, gave coefficients of variation on seven different plates not exceeding $9 \%$ for all four subclasses.

The Mann-Whitney U test with correction for ties was used in the statistical analyses of the results and a two tailed $\mathrm{p}<0.05$ was considered significant.

\section{Results}

The individual values and the geometrical mean concentrations and \pm 1 SD of the four IgG subclasses in the controls and children with Down's syndrome are presented in figs 1 and 2 and the table. There were no significant age 

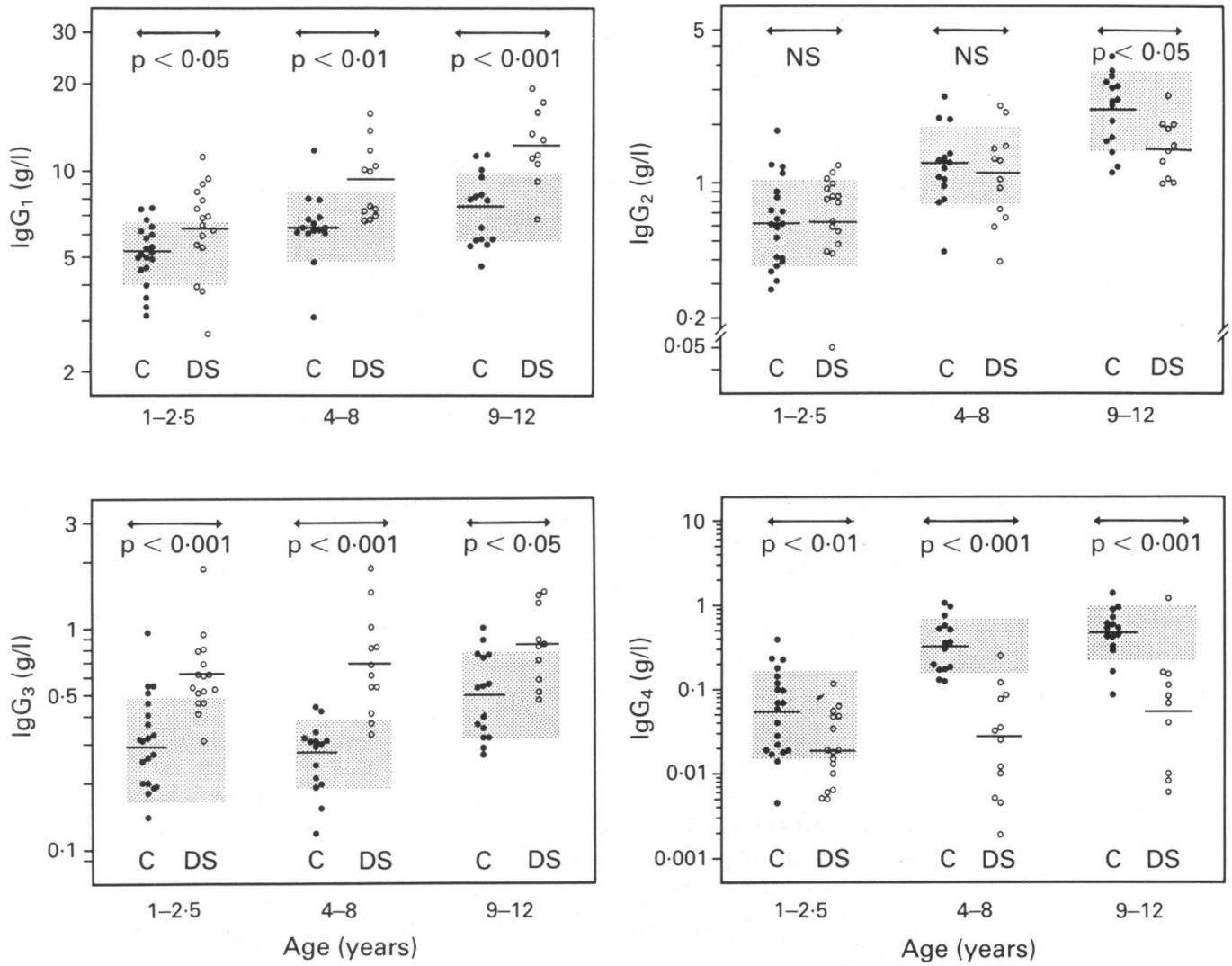

Figure 1 Individual and geometrical mean concentrations of the four IgG subclasses in children with Down's syndrome (DS) and control children $(C)$. The children are split into three age groups $(1-2 \cdot 5,4-8$, and $9-12$ years). The \pm 1 of the geometrical mean concentrations of healthy children are indicated (shaded area). The levels of significance are given in the figure.
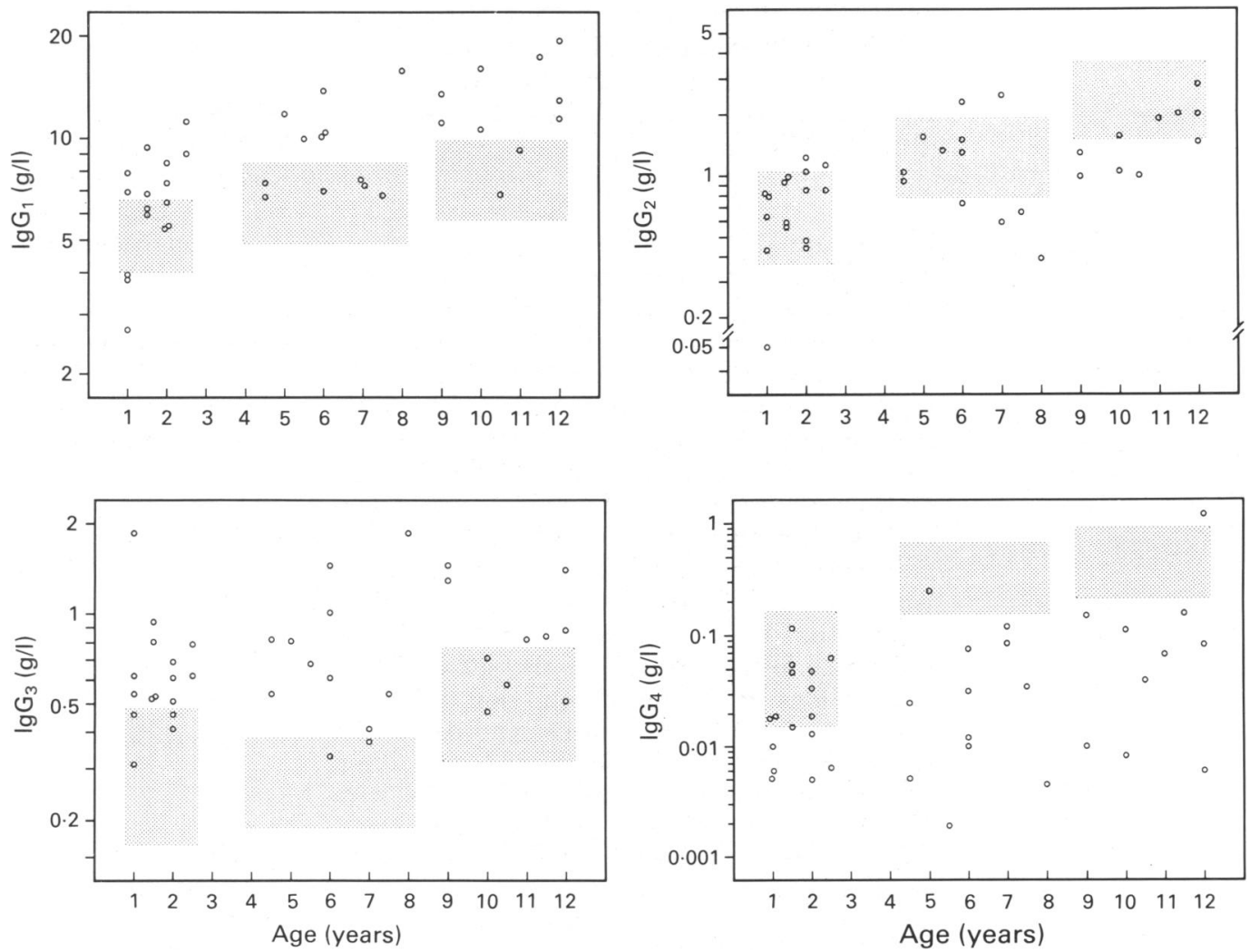

Figure 2 Individual concentrations of the four IgG subclasses in children with Down's syndrome in relation to age. The geometrical mean $\pm 1 S D$ of healthy children are indicated (shaded area). 
IgG subclass concentrations $(\mathrm{g} / \mathrm{l})$ in serum of children with Down's syndrome compared with healthy age matched control children in three age groups. Geometrical means $(G M) \pm I S D$ are presented

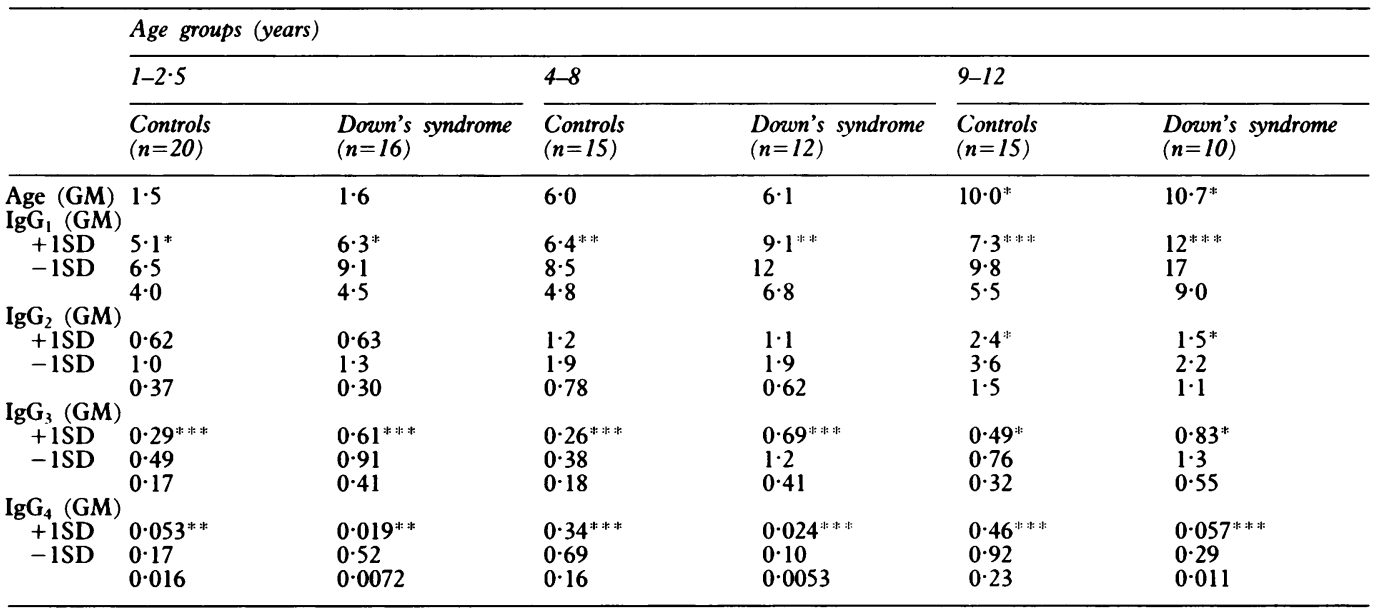

Calculated significance levels in Mann-Whitney U test: ${ }^{*} p<0 \cdot 05, p<0 \cdot 01,{ }^{\text {**: }} \mathrm{p}<00.01$.

differences between controls and children with Down's syndrome in the two youngest groups, but the children with Down's syndrome were slightly older than the controls in the oldest age group $(p=0.04)$ (table). The children with Down's syndrome had significantly higher concentrations of $\operatorname{IgG}_{1}$ (figs 1 and 2, upper left) and $\mathrm{IgG}_{3}$ (figs 1 and 2 , lower left) than the controls in all three age groups. In contrast, the serum concentrations of $\operatorname{IgG}_{2}$ were normal in the children with Down's syndrome in the two youngest age groups but significantly reduced among the oldest children with Down's syndrome (figs 1 and 2 , upper right). The IgG $_{4}$ concentrations were significantly reduced in all three age groups of children with Down's syndrome (figs 1 and 2, lower right). In fact, in the two age groups with the oldest children, 68\% (15/22) had $\mathrm{IgG}_{4}$ concentrations below $2 \mathrm{SD}$ from the geometrical mean.

\section{Discussion}

The higher serum concentrations of IgG subclasses 1 and 3 in the children with Down's syndrome compared with the controls may well be a consequence of polyclonal stimulation from repeated bacterial infections, which obviously does not include $\operatorname{IgG}_{2}$ and $\mathrm{IgG}_{4}$. This contrast strengthens the concept that children with Down's syndrome fail to respond properly with antibodies of the latter subclasses. The results are in accordance with recent data for adults with Down's syndrome ${ }^{8}$ and for children concerning $\mathrm{IgG}_{4}{ }^{9}$ and are likely to be of pathogenetic significance for the susceptibility to infections. It is interesting to note that $\mathrm{IgG}_{4}$ deficiency is found in Down's syndrome at all ages, ${ }^{89}$ but an IgG $_{2}$ deficiency tends to develop later in life among children and adults with Down's syndrome. ${ }^{8}$ Thus the $\mathrm{IgG}_{4}$ deficiency is not accompanied by an $\operatorname{IgG}_{2}$ deficiency in childhood in Down's syndrome.

Children with Down's syndrome are especially prone to respiratory bacterial infections. ${ }^{4}$ This may be partially explained by a deficiency in $\mathrm{IgG}_{2}$ and $\mathrm{IgG}_{4}$ antibodies, of which the former are known to be directed primarily against bacterial polysaccharide antigens of encapsulated bacteria, such as Diplococcus pneumoniae and Haemophilus influenzae. ${ }^{12}$ Even though the serum concentration of $\mathrm{IgG}_{4}$ is low, it may play a part in mucosal defence because of its higher relative concentration in secretions. ${ }^{13}$ Virus specific IgG antibodies are often of subclasses 1 and 3.12

The mechanism underlying the abnormal serum IgG subclass pattern is probably not a gene dosage effect as none of the chromosome 21 genes are known to regulate immunoglobulin production. Secondary effects of either a factor related to immunoglobulin production or a deficiency of a trace element such as selenium ${ }^{14}$ are proposed as alternative explanations. We have recently reported that selenium supplementation in children with Down's syndrome has a significant augmentative effect on the serum concentrations of $\operatorname{IgG}_{2}$ and $\mathrm{IgG}_{4}$, but not on those of $\mathrm{IgG}_{1}$ and $\mathrm{IgG}_{3} .{ }^{14}$

Although the mechanism behind the abnormal subclass pattern in individuals with Down's syndrome is unknown, it seems relevant to assay the IgG subclass concentrations among patients with Down's syndrome who have repeated infections. If only the total serum IgG concentration is assayed a deficiency in the $\mathrm{IgG}_{2}$ and $\mathrm{IgG}_{4}$ subclasses will escape detection.

The skilful technical assistance of Mrs Maggy Magnusson is acknowledged. This study was supported by grants from the acknowledged. This study was supported by grants from the Sävstaholm Society, the Marcus Borgström Foundation, and the
Swedish Medical Research Council (grants 5445 and 16X-105).

1 Burgio GR, Ugazio AG, Nespoli L, Marcioni AF, Bottel AM, Pasquali F. Derangements of immunoglobulin levels phytohemaglutinin responsiveness, and $\mathrm{T}$ and $\mathrm{B}$ cell markers in Down's synd

2 Stiehm ER, Fudenberg HH Serum levels of immunoglobulins in health and disease: a survey. Pediatrics globulins in healt

3 Biörkstén B, Bäck $O$, Hägglöf $B$, Tärnvik A. Immune function in Down's syndrome. In: Guttler F, Seakin JWT function in Down's syndrome. In: Guttler F, Seakin JWT, cytosis. Lancaster: MTP Press, 1979:189-98.

4 Annerén G. Björkstén B. Low superoxide levels in blood phagocytic cells in Down's syndrome. Acta Paediatr Scand 1984;73:345-8.

5 Levin S. The immune system and susceptibility to infections 
in Down's syndrome. In: McCoy EE, Epstein CJ, eds. Oncology and immunology of Down's syndrome. New York: Alan R Liss, 1987:143-62.

6 Funa K, Annerén G, Alm G, Björkstén B. Abnormal interferon production and $\mathrm{NK}$ cell responses to interferon in children with Down's syndrome. Clin Exp Immunol 1984;56:493-500.

7 Nishida Y, Sano Y, Akaoka I. Abnormal serum immunoglobulin levels in Down's syndrome patients. American fournal of Mental Deficiency 1978:83:16-20.

8 Avanzini MA, Söderström T, Wahl M, Plebani A, Burgio GR, Hanson $\AA$. IgG subclass deficiency in patients with Down's syndrome and aberrant hepatitis $B$ vaccine response. Scand F Immunol 1988;28:465-70.

9 Loh RKS, Harth SC, Thong YH, Ferrante A. Immunoglobulin G subclass deficiency and predisposition to infection in Down's syndrome. Pediatr Infect Dis 7 1990;9: 547-51.
10 Lee SI, Heiner DC, Wara D. Development of serum IgG subclass levels in children. Monogr Allergy 1987;19:108-21.

11 Klein F, Skvaril F, Vermeeren R, Vlug A, Duimel WJ. The quantification of human IgG subclasses in reference preparation. Clin Chim Acta 1985;157:119-27.

12 Siber GR, Schur PH, Alsenberg AC, Weitzman SA, Schiffman

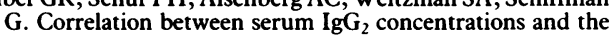
antibody response to bacterial polysaccharide antigens. $N$ Engl F Med 1980;303:178-82.

13 Merrill MW, Naegel GP, Olchowski JJ, Reynolds HY. Immunoglobulin $\mathrm{G}$ subclass proteins in serum and lavage fluid of normal subjects, quantitation and comparison with immunoglobulins A and E. Am Rev Respir Dis 1985;131: immun 7 .

14 Annerén G, Magnusson CGM, Nordvall SL. Increase in serum concentrations of $\mathrm{IgG}_{2}$ and $\mathrm{IgG}_{4}$ by selenium supplementation in children with Down's syndrome. Arch Dis Child 1990;65:1353-5.

The uses of laparoscopy*

If the October 1991 issue of the fournal of Pediatric Surgery is anything to go by, laparoscopy is something of a buzz word in paediatric surgical circles at the moment. It contains five articles about laparoscopic surgery: three about cholecystectomy, ${ }^{1-3}$ one about pyloromyotomy,${ }^{4}$ and one about untwisting a torsion of the uterine adnexa. ${ }^{5}$

Gallbladder disease in children is not common (see Archivist 1991:940) but not rare and workers in Montreal, ${ }^{1}$ Washington DC, and Nashville, Tennessee ${ }^{3}$ report a total of 13 laparoscopic cholecystectomies in children between the ages of 7 and 16 years. There were no complications and the children were less distressed postoperatively and recovered quicker.

A report from Limoges, France describes the treatment of 10 babies with pyloric stenosis using laparoscopic pyloromyotomy. ${ }^{4}$ The operation was successful and without complications in all 10 . The final article in the series is one from Israel reporting the use of laparoscopic surgery in a girl of 11 years with torsion of the uterine adnexa. ${ }^{5}$

An accompanying editorial discusses the advent of laparoscopic surgery (laparoscopic cholecystectomy in adults was first described in 1989) and lays emphasis on the need to ensure adequate training in these techniques and the potential for disaster in inexperienced hands. ${ }^{6}$ Clearly any surgeon new to the technique should at first operate only under supervision. According to the team in Nashville it takes some 15 to 20 operations to become competent.

ARCHIVIST

1 Sigman HH, Laberge J-M, Croitou D, et al. Laparoscopic cholecystectomy: a treatment option for gall bladder disease in children. F Pediatr Surg 1991;26:1181-3. treatment option for gall bladder disease in children. F Pediatr Surg 1991;26:1181-3.
Newman KD, Marmon LM, Altorri R, Evans S. Laparoscopic cholecystectomy in pediatric patients. F Pediatr Surg 1991;26:1184-5.

3 Holcomb GW, Olsen DO, Sharp KW. Laparoscopic cholecystectomy in the pediatric patient. F Pediatr Surg 1991;26:1186-90.

4 Alain JL, Grousseau D, Terrier G. Extramucosal pylorotomy by laparoscopy. F Pediatr Surg 1991;26:1191-2.

Shalev E, Mann S, Romano S, Rahav D. Laparoscopic detorsion of adnexa in childhood: a case report. $\mathcal{F}$ Pediatr Surg 1991;26:1193-4.

6 Sackier JM. Laparoscopy in pediatric surgery. F Pediatr Surg 1991;26:1145-7.

"A good title is worth imitating. Richard Hoggart's best known book, The Uses of Literacy, was published in 1957 and stays in the memory, I suspect, largely because of its title. In fact, it was to have been called 'the abuses of literacy', but was changed because of the objections of a libel lawyer. By the time I got round to reading it, it was way out of date and not very relevant. I enjoyed the first part of his autobiography ${ }^{7}$ though and am settling into the second ${ }^{\mathrm{x}}$; recommended reading for when you've finished the Archives and want a break from paediatrics.

7 Hoggart R. A local habitation. (Life and times. Vol 1. 1918-40.) London: Chatto and Windus, 1988.

8 Hoggart R. A sort of clowning. (Life and times. Vol 2. 1940-59.) Oxford: Oxford University Press, 1991. 